\title{
DO FOREST CONCESSIONS BENEFIT EXTRACTIVIST COMMUNITIES? THE CASE OF THE JAMARI NATIONAL FOREST
}

\author{
Roni Djeison Ansolin ${ }^{1 *}$, Ana Paula Donicht Fernandes², Romano Timofeiczyk Junior ${ }^{3}$, Vitor Afonso Hoeflich³, \\ Marco Antônio Bento ${ }^{1}$, Samuel Alves da Silva ${ }^{1}$ \\ ${ }^{1 *}$ Federal University of Paraná, Graduate Program in Forest Engineering, Curitiba, Paraná, Brazil - roni_ansolin@ @otmail.com*; \\ marcoanbento@gmail.com; ssilva.alves@yahoo.com.br \\ ${ }^{2}$ Federal Rural University of Amazonia, Capitão Poço, Pará, Brazil - anapauladfernandes@yahoo.com.br \\ ${ }^{3}$ Federal University of Paraná, Department of Rural Economy and Extension, Curitiba, Paraná, Brazil - romano.timo@ gmail.com; \\ vitor.ufpr@gmail.com
}

Received for publication: 11/11/2018 - Accepted for publication: 10/09/2019

\begin{abstract}
Resumo
As concessões florestais podem beneficias as comunidades extrativistas? O caso da Floresta Nacional de Jamari. O estudo tem como objetivo analisar o potencial exploratório dos principais produtos florestais nãomadeireiros da Unidade de Manejo Florestal III pelas comunidades do entorno da Floresta Nacional do Jamari. Foram utilizados os dados de produção de açaí e castanha do Brasil apresentados no Plano de Manejo Florestal de Produtos não Madeireiros, bem como os dados de produção de castanha do Brasil coletados pelas comunidades tradicionais, "Américo Ventura" e "Linhas 113-119". Foram calculados indicadores econômicos por meio dos dados de produção. Como principais resultados, o potencial produtivo de açaí e castanha do Brasil anual da UMF III é de 426,86 toneladas e 124,13, respectivamente, proporcionando uma estimativa de renda anual de R \$ 79.794,64 e R \$ 195.134,63, respectivamente. Para a castanha do Brasil, a demanda anual levantada pela comunidade foi de aproximadamente 8 toneladas, de 2015 a 2017. A quantidade colhida representa 44,77\% da capacidade produtiva das três unidades. Além disso, a relação custo-benefício indica que, para cada real investido na produção, o produtor recebe, em média, $\mathrm{R} \$$ 5,72. A extração da castanha brasileira mostra-se uma atividade interessante em termos de produção e valor econômico em ambas as comunidades, apresentando um ganho líquido anual de $\mathrm{R} \$ 1.812 .108$ por extrativista, para um total de 50 extrativistas residentes nas comunidades Américo Ventura e "Linhas 113-119", entre 2015 e 2017. Assim, conclui-se que existe um grande potencial de exploração desses produtos em parceria com a concessão florestal, contribuindo para o desenvolvimento sustentável das comunidades extrativistas.

Palavras-chave: Indicadores econômicos; produtos florestais não-madeireiros, manejo florestal.
\end{abstract}

\begin{abstract}
The study aims to analyze the exploration potential of the main non-timber forest products in the Forest Management Unit number III by the communities around Jamari National Forest. Were used the açaí fruit and Brazilian nuts production data based on the sustainable management plan, as well the Brazilian nut crop production for 2015, 2016 and 2017 reported by traditional communities, "Américo Ventura" and "Linhas 113119". The data were analyzed and interpreted using economic indicators. As the main results, the productive potential amount of açaí fruit and Brazilian nuts available for harvest in each annual crop is 426,86 tons and 124,13 tons, respectively, providing an estimate of annual income of $\mathrm{R} \$ 79.794,64$ and $\mathrm{R} \$ 195.134,63$, respectively. For Brazilian nuts, the annually demand raised by the community was approximately 8 tons, from 2015 to 2017 . The amount harvested represents $44.77 \%$ of the productive capacity of the three units. In addition, the cost-benefit ratio indicates that for each Brazilian Real invested in production the producer receives, on average, $\mathrm{R} \$ 5,72$. The Brazilian nut extraction shows to be an interesting activity in terms of production and economic value in both communities, presenting a net annual gain of $\mathrm{R} \$ 1.812,108$ per collector, for a total group of 50 extractivists residing in the communities "Américo Ventura" and "Linhas 113-119", between 2015 to 2017. Thus, it is concluded that there is a great potential for exploration of these products in partnership with the concession forest, contributing to the sustainable development of extractivist communities.

Keywords: Economic indicators; non-timber Forest Products, forest management.
\end{abstract}

\section{INTRODUCTION}

The productive exploitation of forests does not always represent degradation. It is possible to adopt, in this type of natural wealth, several economic mechanisms with socio-environmental responsibility. However, it is necessary to have normative instruments that systematize and make feasible this type of production, in the sense of curbing other mechanisms that do not correspond to the sustainability standards (MARQUES et al., 2009). 
According to the National Register of Public Forests (CNPF, 2015), there are currently 310.7 million hectares of public forests registered in Brazil, equivalent to $36.5 \%$ of the Brazilian territory. Of this value, 51.7\% correspond to public forests for community use, $14.7 \%$ for biodiversity protection, $9.9 \%$ for sustainable use and $0.9 \%$ for military use. The management of these forests for sustainable production includes the creation of National Forests (NF), (that constitute a modality of conservation unit of the sustainable use group) the destination to local communities and forest concession (BRASIL, 2006).

Since 2006, the Brazilian Government may grant to companies and communities the right to exploit public forests to extract timber and non-timber products, and offer tourism services. In return, the concessionaires must pay the government amounts according to the proposed price presented during the bidding process of these areas. One of the criteria for the selection of the forest concessionaire is the commitment of the concession-winning company to develop actions aiming to invest in infrastructure and services for the local community (MMA, 2007).

The Brazilian Forest Service has contracts for forest concession in six National Forests in Pará and in Rondônia. In total, more than one million hectares are under forest concession and will be managed sustainably by ten companies for 40 years. In the period from 2011 to 2017, the National Forest of Jamari produced an approximate volume of 215 thousand $\mathrm{m}^{3}$ of $\operatorname{logs}$ and in the National Forest of Saracá-Taquera, between 2012 and 2017, approximately 186 thousand $\mathrm{m}^{3}$ of the product were produced (SFB, 2019).

In world terms, the dense commercial stocking of forests in Southeast Asia have made it the leading tropical logging region ( 85.56 million $\mathrm{m}^{3}$ in 2012 to be compared to tropical Africa that produced 28.50 million $\mathrm{m}^{3}$ and Latin America 39.94 million $\mathrm{m}^{3}$ ). Concession size vary from small areas to areas larger than 100,000 ha, given in contract for periods ranging from one to one hundred years. In some cases, the land under forest concession is allocated for oil palm, rice, rubber, coffee and other crops (FAO, 2016).

Additionally, the exploitation of public forests must follow a series of principles, regulated by the Law no. 11.284/2006 (BRASIL, 2006), which aim to contribute to an efficient and sustainable exploratory management. Among these principles, we highlight the promotion of local processing and the incentive to increase added value to forest products and services. One of the means to achieve these principles and criteria is to develop a proposal for a Sustainable Forest Management Plan focused on the feasibility of Non-Timber Forest Products (NTFPs) collecting.

The extractivist activity, especially those relate with NTFPs, has always been present in the Amazonian communities, but comprising an incipient portion of the income. In this way, the Brazilian Forest Service (SFB, 2019) also points out that public forests have great social and economic relevance because they generate essential timber and non-timber forest products for their inhabitants. These forests are home for two million people, including traditional people, communities, family farmers and agrarian reform settlers.

Among the forests with the operational management plans, Jamari NF in the state of Rondônia was the first to be submitted to the forest concession process in Brazil, which has an enormous potential for production, especially of açaí fruit and Brazilian nut. In general, in the state of Rondônia, the largest production stands out for the region of Porto Velho (capital city of Rondônia state), with 53\% of the production of açaí fruit and 59\% of Brazilian nut (IBGE, 2016), being also the place of insertion of the Nation Forest of Jamari.

Therefore, we work on the hypothesis that the forest concession could contribute to technic enhancement and adding value at the NTFP supply chain of the communities surrounding the national forests granted.

Thus, in this article, we carried out an analysis on the exploitation of the main non-timber forest products in the Forest Management Unit III (FMU III) by the communities around the Jamari National Forest. More specifically, we present a historical background of the communities around the Jamari NF and an economic analysis of NTFP harvesting, in order to verify the contribution of income generated through the organization of the extraction of açaí fruits (Euterpe precatoria) and Brazilian nuts (Bertholletia excelsa) fostered by forest company concession, and finally to identify the actions of the instruments of policies aiming to enhance the NTFPs sustainable use.

\section{MATERIAL AND METHODS}

\section{Study Area}

Since 2009, three (I, II and III) Forest Management Units located in the Jamari National Forest were granted to exploitation, under authorization by Brazilian Institute of the Environment and Renewable Natural Resources (IBAMA), as well after approval of Sustainable Forest Management Plan.

The research was carried out at the FMU III of Jamari NF, located at the geographical coordinates:

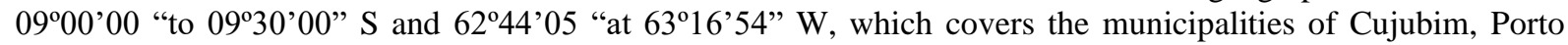
Velho, Ariquemes and Itapuã do Oeste in the State of Rondônia. The National Forest of Jamari was created on 
September 25, 1984, with an approximate area of 220 thousand hectares, of which 96 thousand were destined for forest concession (MMA/IBAMA, 2007).

From the total forest area, the FMU 3, has an area of 46,184,253 hectares, located in the southwestern part of the Jamari National Forest, located, in most part, at the municipality of Itapuã do Oeste (about 95\%). The predominant phyto-physiognomy is characterized by dense/submontane ombrophilous forest (BASTOS et al., 2014).

According to the classification of Köppen, the region integrates the "Awi" morph climatic framework, characterized by seasons of hot and humid climate, with a short dry season (tropical with monsoon rains), presenting average temperature of $22^{\circ} \mathrm{C}$ and precipitation from 1750 to $2750 \mathrm{~mm} /$ year (ALVARES et al., 2013). It presents the following types of soils: Dystrophic Yellow Latosol, Dystrophic Yellow Red Latosol, Dystrophic Dark Red Latosol and Dysosomal Regosol.

\section{Source of data}

In order to gain a deeper insight about historical and socio-economic issues, into the traditional communities (Américo Ventura and the "Linhas 113-119") around the Jamari National Forest, bibliographic survey were carried out into the online library of forest concession company website. A total of seven documents were consulted - Plano de Manejo Florestal de Produtos não Madeireiros - Jamari (2015); Plano de Manejo Florestal Sustentável da UMF III da Flona do Jamari (2009); Controle de Acesso à UMF III (2016); Análise socioeconômica e ambiental do entorno da área de concessão pública - UMF III na floresta nacional do Jamari (2009); Resumo Anual do Plano de Manejo Florestal Sustentável da UMF III da Flona do Jamari (2015, 2016, 2017).

Furthermore, the present study used data on the potential production of açaí fruits (Euterpe precatoria) and Brazilian nuts (Bertholletia excelsa) by Annual Production Unit (APU). The production data was based on forest inventory carried out by the technical team of the timber concession company. The estimation of the productive potential of açaí fruit took into consider the average of two bunches per palm, each with $4.5 \mathrm{~kg}$, leading to the production of $423,59 \mathrm{~kg} / \mathrm{ha} /$ year in the in floodplain (Baixio) and 23,58 kg / ha / year in upland (Terra Firme) forests, according to registered in the non-timber forest products sustainable management plan of Jamari national forest. For Brazilian nuts the estimation of the productive potential took into consider an average density of 54 chestnut trees every 100 hectares $(0.54$ / ha) in the area, also that in each fruit there are $170 \mathrm{~g}$ of nuts, according to the average determined by sampling of 587 fruits of six chestnut trees on the sustainable management plan.

In addition, the price consultation for açai fruit and Brazilian nut was consider the price negotiated at the local market by collectors. Thus, for açaí fruit and Brazilian nut the price considered was $\mathrm{R} \$ 3,20$ and $\mathrm{R} \$ 4,50$ per kilo, respectively.

For the purposes of calculating the economic indicators, only data from Brazilian nut production was used, due to harvesting permission assigned in the Forest Management Plan, although the harvesting will be allowed over the concession period for açaí fruit.

Specifically, for the economic analysis, the costs considered were manpower ( $\$ 60$ per day), depreciation of the storage location (10\% per year), equipment maintenance (R $\$ 87,60$ per month) transportation ( $\mathrm{R} \$ 428,00$ per month) and materials required for extraction ( $\mathrm{R} \$ 489,00$ per year), and the crop production of 2015 , 2016, 2017. Thus, based on the production and costs reported by the collectors and in the management plan, it was possible to calculate the profitability of the extraction activity for Brazil nuts.

\section{Data analysis}

The analysis and interpretation of data were carried out using economic indicators, as suggested for Maciel et al. (2014). Four indicators were analyzed to understand the economic profitability of the NTFP production:

a) Total Cost (TC): Is the sum of expenditure on inputs and temporary labor in the activity, Variable Cost (materials, equipment and transportation), Fixed Cost (depreciation and maintenance), defined by formula 1.

$$
T C=T V C+T F C
$$

Being that:

$T C=$ total cost;

$T V C=$ total variable cost;

$T F C=$ total fixed cost.

FLORESTA, Curitiba, PR, v. 50, n. 2, p. 1297 - 1306, abr/jun 2020

Ansolin, R. D. et.al.

ISSN eletrônico 1982-4688

DOI: $10.5380 /$ rf.v50 i2. 62742 
b) Gross Income (GI): production scale indicator, defined by formula 2 .

Being that:

$$
G I=\sum_{i=1}^{n}(P i Q i)
$$

$G I=$ Gross income from production (in this case, production of Brazilian nuts);

$P i=$ price paid to the producer for the product $I,(I=1,2 \ldots n)$;

$Q i=$ produced quantity of the product $i$.

c) Net Revenue (NR): is the difference between Gross Income and Total Cost, defined by the formula 3 .

Being that:

$$
N R=G I-T C
$$

$N R=$ net revenue;

$G I=$ gross income;

$T C=$ total cost .

d) Economic Efficiency Index (EEI): benefit/cost indicator, defined by the formula 4.

$$
E E I=\frac{G I}{T C}
$$

Being that:

$G B=$ Gross Income;

$T C=$ Total cost.

And:

EEI $>1$, the situation is for profit.

EEI $<1$, the situation is for loss.

$\mathrm{EEI}=1$, the situation is for balance.

\section{RESULTS}

The traditional communities around the Jamari NF are linked to extractive and agricultural activities, many of which are part of associations and cooperatives. Currently, there are two main communities harvesting NTFP around the Jamari NF called "Américo Ventura" and "Linhas 113-119".

The activity of extractivism is concentrated in the following products: Brazilian nuts and açaí fruits, more abundantly, and copaiba and patuá, in a much-reduced proportions. Table 1 shows estimates of values that communities can achieve in each annual production unit, considering an average for the annual harvest, following the Sustainable Forest Management document approved by IBAMA.

Table 1. Estimation of the productive potential and economic value for açaí fruit and Brazilian nuts in the FMU 3 of Jamari NF.

Tabela 1. Estimativa do potencial produtivo e valor econômico do açaí e da castanha do Brasil na UMF 3 da Flona do Jamari.

\begin{tabular}{cccc}
\hline APU & Area (ha) & $\begin{array}{c}\text { Potential productive } \\
\text { (ton/year) }\end{array}$ & $\begin{array}{c}\text { Potential total revenue } \\
\text { for annual/APU (R\$) }\end{array}$ \\
\hline 1 & Açaí fruit & \\
2 & $1.562,62$ & 54,64 & $174.851,20$ \\
3 & $1.919,28$ & 67,11 & $214.758,40$ \\
8 & $1.899,01$ & 66,41 & $212.499,20$ \\
9 & $1.699,46$ & 59,43 & $190.163,20$ \\
16 & $1.452,45$ & 53,80 & $172.166,40$ \\
25 & $1.796,49$ & 62,82 & $201.020,80$ \\
Total & $1.791,69$ & 62,65 & $200.483,20$ \\
\hline
\end{tabular}




\begin{tabular}{cccc}
\hline \multicolumn{4}{c}{ Brazilian nut } \\
\hline 1 & $1.562,62$ & 16,20 & $72.918,00$ \\
2 & $1.919,28$ & 18,92 & $85.158,00$ \\
3 & $1.899,01$ & 19,37 & $87.165,00$ \\
8 & $1.699,46$ & 17,33 & $78.003,00$ \\
9 & $1.452,45$ & 15,69 & $70.623,00$ \\
16 & $1.796,49$ & 18,32 & $82.458,00$ \\
25 & $1.791,69$ & 18,28 & $82.237,50$ \\
\hline Total & $\mathbf{1 2 . 1 2 1}$ & $\mathbf{1 2 4 , 1 3}$ & $\mathbf{5 5 8 . 5 6 2 , 5 0}$ \\
\hline
\end{tabular}

Due to the restriction of people entering the collection activity inside the National Forest, as well as the need for the collectors to attend specific harvest training, a maximum of 10 collectors (Table 2) were authorized for the Brazilian nut harvesting, for the 2015 crop. Although, for the 2016 and 2017 crop the collector trained increased, it allows him the permission to harvest the NTFPs.

Table 2. Brazilian nut production harvested by the surrounding communities of the Jamari National Forest.

Tabela 2. Produção anual de castanha do Brasil colhida pelas comunidades do entorno da Flona do Jamari.

\begin{tabular}{cccc}
\hline $\begin{array}{c}\text { Crop } \\
\text { season }\end{array}$ & APU & $\begin{array}{c}\text { Production of Brazilian nut (with } \\
\text { peel) ton }\end{array}$ & Number of collectors \\
\hline 2015 & 1 & 0,4 & 10 \\
2016 & 2 & 9 & 22 \\
2017 & 3 & 15 & 18 \\
\hline Total & & $\mathbf{2 4 , 4}$ & $\mathbf{5 0}$ \\
\hline
\end{tabular}

Table 3 .

The total income and cost involved in the Brazilian nut extraction activity for this study are showed at

Table 3. Estimated economic indicators of Brazilian nuts crop, between 2015 to 2017, for APU 1, 2 and 3 in the FMU 3, at National Forest of Jamari.

Table 3. Indicadores econômicos da produção de castanha do Brasil, entre 2015 e 2017, para APU 1, 2 e 3 na UMF 3, na Floresta Nacional do Jamari.

\begin{tabular}{cccccc}
\hline $\begin{array}{c}\text { Quantity } \\
(\mathrm{kg})\end{array}$ & $\begin{array}{c}\text { Price }^{1} \\
(\mathrm{R} \$ / \mathrm{kg})\end{array}$ & Income gross $(\mathrm{R} \$)$ & $\begin{array}{c}\text { Total Cost } \\
(\mathrm{R} \$)\end{array}$ & $\begin{array}{c}\text { Net revenue } \\
(\mathrm{R} \$)\end{array}$ & EEI \\
\hline $24.400,00$ & 4,50 & $109.800,00$ & $19.194,60$ & $90.605,40$ & 5,72 \\
\hline
\end{tabular}

${ }^{1}$ The price for Brazilian nuts with peel.

\section{DISCUSSION}

It was identified that the "Américo Ventura" community arose in 1995 as a consequence of the conflict that occur in Corumbiara settle, where 22 settled families were displaced by the Brazilian Institute of Colonization and Agrarian Reform (INCRA) to the present location, in addition, some families came from the municipalities of Ariquemes, Ji-Paraná, Cacoal and Cujubim. Currently, the community is made up of a population of 68 families. The main productive activities are the cultivation of pineapple, coffee, urucum, guarana, and dairy cattle and cutting. The community holds basic infrastructure, such as good quality electric power supply, health posts and a school that serves the local population and other surrounding communities.

Another important community is "Linha 113-119" that began their settlement in the 1990s through a settlement process directed and carried out by INCRA. Among the settlers, there were families residing within the current Jamari NF conservation unit area, which were removed from the area and settled in the surrounding area. Even today, archaeological remains are found due to occupation by indigenous peoples in 
the past. Initially, the main activity of income was the hunting, cultivation of cassava and extraction of syringe and Brazilian nut.

The communities around the Jamari NF have a very low health infrastructure, as well as a poor quality of education with a precarious structure situation in the community schools. However, it was possible to verify that the forest concession companies have sought to implement projects in the areas of health and education that have been contributing to the development of communities.

Based on the production values of the NTFPs inventory (Table 1), it was possible to highlight the high economic potential of the forest, stating that through management techniques communities can sustainably exploit resources, allowing a significant income increase in their income.

The current availability of NTFPs at FMU III of Jamari NF indicates a great potential for exploration of these products in partnerships with the concessionaire legally responsible for forest management, a model that has contributed to the planning of the extraction by the communities, as well as in the price negotiations of the Brazilian nuts and açaí fruit, ensuring safety in the sale of products. A similar pattern was found in Ipponga et al (2018) when analyse livelihood activities of rural households around two forest concessions in Gabon. The authors affirm that NTFPs represent great potential for generating higher and diversified incomes for households and the national economy, especially as revenue from the non-renewable oil sector dwindles.

The productive potential for both NTFPs in the FMU III of Jamari NF shows that the amount of açaí fruit and Brazilian nuts available for harvest in each annual crop is 426,86 tons and 124,13 tons, respectively, providing an estimate of annual income of $\mathrm{R} \$ 79.794,64$ in the collection of açaí fruit and $\mathrm{R} \$ 195.134,63$ of Brazilian nut collection. However, for Brazilian nuts, the annually demand raised by the community was approximately 8 tons, from 2015 to 2017. The amount harvested (Table 2) represents $44.77 \%$ of the productive capacity of the three units. Considering the average sale price of $R \$ 4,50$ per kilogram of Brazilian nuts, the gross economic value of production was $\mathrm{R} \$ 109.800,00$.

Notwithstanding the potential production exceeding actual harvest and the continuous demand for the product by the families surrounding the Jamari NF, the lack of interest of young people in continuing these activities contributes to hamper increase production to the full potential. Also, through actions in partnership with the company of the forest concession, the collectors are benefited in the reduction of the costs with the extraction.

Arnold e Pérez (2001) argue that the growing interest in NTFPs by these communities, during the last 10-20 years, arose from the perception of non-financial attributes of NTFP's. First, NTFPs contribute in important ways to livelihoods and the welfare of populations living in and adjacent to the forest. Second, exploitation of NTFPs is seen as less ecologically destructive than timber harvesting (GUBBI; MACMILLAN, 2008; MUKUL et al., 2010). Thirdly, recognizing those social and environmental contributions and that they are increasing in value should add to the perceived value of the forests by both local peoples and national governments, thereby increasing the incentives for conservation of those resources at both local and national scale.

For Medina et al. (2009), community-based forest management encompasses all forest resource management activities that have as their fundamental purpose to improve the social, economic, emotional and environmental conditions of rural communities, based on their own reality and perspectives. Arruda (1999) states that, in general, the Brazilian traditional communities adopt a model of occupation of space and use of natural resources focused on subsistence, with poor articulation with the market, based on the intensive use of family labor, technologies of low impact derived from inherited knowledge and, normally, on a sustainable basis.

In addition, the economic indicators in Table 3 indicate that Brazilian nut production is widely favorable for commercialization. However, it is important to note that prior to the forest concession the communities did not collect non-timber products for sale at scale, only for their own consumption and some local sales. Collecting, processing and consumption of these two forest products represent important activities locally, culturally as well as socially and economically, even though the diffusion and practice of agriculture and conventional livestock farming in the region still prevails. The findings of this study are in line with Ipponga (2018) when find that even around the forest concessions, the value of agricultural products for subsistence and income generation is much higher than that of NTFPs of plant origin. 
The cost-benefit ratio indicates that for each Brazilian Real invested in production the producer receives, on average, $R \$ 5,72$. The Brazilian nut extraction shows to be an interesting activity in terms of production and economic value in both communities, presenting a net annual gain of $\mathrm{R} \$ 1.812,108$ per collector, for a total group of 50 extractivists residing in the communities "Américo Ventura" and "Linhas 113-119", between 2015 to 2017. Considering the average sale price of $\mathrm{R} \$ 4,50$ per kilogram of nuts, the gross economic value of production was $\mathrm{R} \$ 109.800,00$.

Nevertheless, after the entry of the forest concession, as mentioned by the communities, the extraction became an important income to the collector's families, contributing significantly to the family budget. This fact can be explained by the decrease in agricultural productivity, environmental restriction, and, specially, the adoption of new techniques such as harvesting and processing, which stimulate the collectors and make the activity attractive to those involved. Additionally, in order to encourage people's involvement, the company also provides personal protective equipment, GPS and maps, as well as a collection techniques training. Although, it's important to notice that not all people that have been trained actually engage in these activities, opting to find other sources of income or even leaving the communities.

The provision of technical assistance, rural extension and community empowerment are considered strategies with a focus on social participation essential for rural development. The organization of collectors through associations and cooperatives seeks to create communities' identity and strengthen management systems at business levels. These tools have been shown to be efficient mechanisms for the rural development of the traditional communities of Amazonia region (FOLETO; LEITE, 2011; COSTA, et al., 2013).

Regarding to the environmental benefits, this study also supports actions of public policy instruments that directly affect the development of traditional communities around the National Forests under concession and for the valorization of non-timber forest products, by a specific program of payment for environmental services. Hence, partnerships with the private sector arises in the context of sustainable development as an economic instrument to promote the conservation of natural resources.

However, corroborated by Nascimento et al. (2013), economic instruments require political, legal and institutional conditions, therefore they are conditioned to a policy objective. Thus, as Oliveira (2006) concludes, one of the reasons for the failure of public policy outcomes is the dissociation between elaboration and implementation in the public policy planning process. In this way, actions like this need attention from the political actors, which if implemented would result in positive contributions to regional sustainable development.

Although collective aspirations and pledges are important tools for communities improve their standard of living, direct actions are required to precipitate on-the-ground change. The vague nature of many company commitments may lead to greenwashing, defined as poor environmental performance accompanied by positive communication about environmental performance (DELMAS; BURBANO, 2011). Actionable initiatives such as forest concession could bridge the gap between traditional communities and timber companies, since it is been built in a multistakeholder initiative based on the sustainable milestone.

The Brazilian forest concession model was designed based on the sustainable forest management, which promote a low environmental impact, engagement with the local community and transparency. Recently, Lambin et al. (2018) concludes and also confirm in their research that governments play an important role in generating incentives and threat of sanctions for adopting sustainable practices, creating and implementing measures and safeguards to avoid perverse effects on small producers. Also, governments can encourage industry self-regulation through the threat of stronger public regulations, endorse and reinforce private standards, facilitate information sharing and supply-chain transparency, cover the costs of compliance of small producers (LAMBIN et al., 2014).

Therefore, managing tropical forests for multiple resources and multiple stakeholders requires processes for negotiation and joint decision making (KARSENTY; VERMEULEN, 2017), going beyond the discussion platforms and committees integrating local users and industries that are mandated by forest laws in the region (CERUTTI et al., 2017).

Lastly, with the monitoring of production and with the populations being supported with capacity building, the company were able to improve management systems that contribute to the local socio-economic development and conservation of forests, mainly due to the opportunity to use the multiple forest resources. 
In addition, it was verified that the access to the resources and the areas to be managed is always carried out with the attendance of a technician of the forest concession company, fulfilling the criteria of identification, regularization and monitoring of the access by the communities.

Finally, we encourage new studies into others national forest with concession rights, in order to see in a larger framework how the forest concessions could benefit communities and environmental protection. Also, we suggest a business plan of NTFP industrialization by the communities to engaging the local people into the forest concession activity.

\section{CONCLUSION}

The analysis allows concluding that:

- The NTFP exploitation is an important activity for the communities around the Jamari National Forest, in view of the economic, social and environmental benefits provided, however is pointed as relevant, the participatory management that involves all the stakeholders (community and companies) in extractive activities.

- Economic indicators indicate that Brazilian nut production is widely favorable for commercialization. Although, it is recommended that the actions of the concessionaires stimulate and value the extraction of non-timber forest products by the communities around them, since they represent activities that are important locally, culturally, socially and economically, despite the practice of agriculture and conventional livestock farming.

- In view of the high productive potential of açaí fruit and Brazilian nuts in Jamari NF, and by favoring the contributions from the forest concession, a business plan for the agro-industrialization of these products and their derivatives should be an immediate agenda. The strengthening of the supply chain can make the product stop being potential and become a present reality.

- Despite policy and institutional improvements in Brazil, there is a lack of data on the value and contribution of NTFPs to the economies of rural households. Programs geared towards increasing public awareness of the NTFP sector is important to achieve the grant mechanisms with regard to the intended aspects of sustainability.

\section{REFERENCES}

ALVARES, C. A.; STAPE, J. L.; SENTELhAS, P. C.; GONÇALVES, J. L. M.; SPAROVEK, G. Köppen's climate classification map for Brazil. Meteorologische Zeitschrift, Berlin, v. 22, n. 6, p. 711-728, 2013.

ARRUDA, R. "Traditional populations" and natural resources protection in conservation units. Revista Ambiente \& Sociedade, São Paulo, v. 2, n. 5, p. 79-92, 1999.

ARNOLD, J. E. M.; PÉREZ, M. R. Can non-timber forest products match tropical forest conservation and development objectives? Ecological Economics, Hanover, v. 39, n.3, p. 437-447, 2001.

BASTOS, A.; MANISESI, V.; PASSOS, E., GOMES, F.B.; UCHÔA, L. F. Physical Environment Aspects as Subsidy to Occupation in Southwest Amazon Conservation Units - A Case Study Relating the Jamari National Forest and its Surrounding Areas. International Journal of Sustainable Land use and Urban Planning, v. 2, n. 2, p. 9-22, 2014.

BRASIL. Lei $\mathrm{n}^{\circ} 11.284$, de 2 de março de 2006. Dispõe sobre a gestão de florestas públicas para a produção sustentável [Bralizian law of Public Forests Management for sustainable production]. Diário Oficial da União, Brasília, DF, dois de março de 2006. Available on: http://www.planalto.gov.br/ccivil_03/ato20042006/2006/lei/111284.htm. Accessed: 05 mai. 18.

CERUTTI, P.O.; LESCUYER, G.; TACCONI, L.; EBA’A ATYI, R.; ESSEIANE, E.; NASI, R.; TABI ECKEBIL, P. P., TSANGA, R. 2017. Social impact of the Forest Stewardship Council certification in the Congo Basin. International Forestry Review, Shropshire, v. 19, n. S2, p. 50-63, 2017.

CNPF. Cadastro Nacional de Florestas Públicas. Brasil [Public Forests National Register. Brazil]. 2015. Available on: http://www.florestal.gov.br/cadastro-nacional-de-florestas-publicas. Accessed 01 dez.18. 
COSTA, R. C.; PIKeTty, M. G.; ABRAmOVAY, R. Pagamentos por serviços ambientais, custos de oportunidade e a transição para usos da terra alternativos: o caso de agricultores familiares do Nordeste Paraense [Payments for ecosystem services, opportunity costs and the transition to alternative land uses: the case of family farmers in the Northeast of Paraense state, Brazil]. Sustentabilidade em Debate, Brasília, v. 4, n. 1, p. 99-116, 2013.

DELMAS, M. A.; BURBANO, V. C. The drivers of greenwashing. California Management Review, Berkeley v. 54, n. 1, p. 64-87, 2011.

FAO. 2016. Current Status of Forest Concessions in Southeast Asia, by, Barney Chan Consultant. Forestry Policy and Institutions Working Paper No. 33. Rome. Available on: http://www.fao.org/forestry/450220f557d8566880c29ada8b134400e42c4e.pdf. Accessed 12 dez 19.

FOLETO, E. M.; LEITE, M. B. Perspective of Payment for Environmental Services and case examples in Brazil. Revista de Estudos Ambientais, Blumenau, v. 13, n. 1, p. 6-17. 2011.

GUBBI, S.; MACMILLAN, D. C. Can non-timber forest products solve livelihood problems? A case study from Periyar Tiger Reserve, India. Oryx, Cambridge, v. 42, n. 2, p. 222-228, 2008.

IBGE. Instituto Brasileiro de Geografia e Estatística. Produção da extração vegetal e silvicultura - PEVS. Produção florestal dos principais produtos florestais não-madeireiros [Brazilian Institute of Geography and Statistics. Production of vegetal extraction and silviculture - PEVS. Forest production of the main non-timber forest products]. Rio de Janeiro: IBGE. $2016 . \quad$ Available on: http://www.sidra.ibge.gov.br/bda/pesquisas/pevs/default.asp/. Accessed: 16 mai. 18.

IPONGA, D.M., Mikolo-Yobo, C., Lescuyer, G. et al. The contribution of NTFP-gathering to rural people's livelihoods around two timber concessions in Gabon. Agroforestry Systems (2018) 92: 157. https://doi.org/10.1007/s10457-016-0022-0

KARSENTY, A.; VERMEULEN, C. Toward "Concessions 2.0": Articulating inclusive and exclusive management in production forests in Central Africa. International Forestry Review, Shropshire, v. 19, n. S2, p. $101-113,2017$.

LAMBIN, E. F.; GIBBS, H. K.; HEILMAYR, R.; CARLSON, K. M.; FLECK, L. C.; GARRETT, R. D.; WAROUX, Y. P.; MCDERMOTT, C. L.; MCLAUGHLIN, D.; NEWTON, P.; NOLTE. C.; PACHECO, P.; RAUSCH, L. L.; STRECK, C.; THORLAKSON, T.; WALKER, N. F. The role of supply-chain initiatives in reducing deforestation. Nature Climate Change, London, v. 8, n. 1, p. 109-116, 2018.

LAMBIN, E. F.; MEYFROIDT, P.; RUEDA, X.; BLACKMAN, A.; BÖRNER, J.; CERUTTI, P. O.; DIETSCH, T.; JUNGMANN, L.; LAMARQUE, P.; LISTER, J.; WALKER, N. F.; WUNDERM, S. Efectiveness and synergies of policy instruments for land use governance in tropical regions. Global Environmental Change, Victoria, v. 28, n. 1, p. 129-140, 2014.

MACIEL, R. C. G.; PENHA, D. de L. B.; CAVALCANTE, P. G.; SOUZA, D. L. de; SILVA, P. A.; SANTOS, F. S. L. Rural development, family farming and non-wood forest products: The case of açaí in Feijó, Acre State, Brazil. Revista de Economia Agrícola, São Paulo, v. 61, n. 1, p. 5-21, 2014.

MARQUES, B. F.; MARQUES, C. R. S.; RORIZ, G. F. S. The concession of public forests. Revista da Faculdade de Direito da UFG, Goiânia, v. 33, n. 2, p. 89-111, 2009.

MEDINA, G.; POKORNY, B.; CAMPBELL, B. Community forest management for timber extraction in the Amazon frontier. International Forestry Review, Shropshire, v. 11, n. 3, p. 408-420, 2009.

MMA. 2007. Ministério do Meio Ambiente. Serviço Florestal Brasileiro. Concessão Florestal [Ministry of the Environment. Brazilian National Forest Service. Forest Concession]. Available on: http://download.uol.com.br/ultnot/flona_jamari.pdf. Accessed: 21 jul. 18.

MUKUL, S. A.; UDDIN, M. B.; A. Z. M. M.; RASHID, FOX., J. Integrating livelihoods and conservation in protected areas: understanding the role and stakeholder views on prospects for non- timber forest products, a Bangladesh case study. International Journal of Sustainable Development and World Ecology, Beijing, v. 17, n. 2, p. 180-188, 2010. 
OLIVEIRA, J. A. P. Desafios do planejamento em políticas públicas: diferentes visões e práticas [Challenges of planning in public policies: different views and practices]. Revista de Administração Pública, Rio de Janeiro, v. 40, n. 2, p. 273-288, 2006.

NASCIMENTO, V. M.; NASCIMENTO, M.; BELLEN, H. M. V. Instruments of public policy and its impacts for sustainability. Gestão \& Regionalidade, São Caetano do Sul, v. 29, n. 86, p. 77-87, 2013.

SFB. Plano Anual de Outorga Florestal: 2019. Brazilian National Forest Service. Ministry of Environment MMA. Brasília: MMA, 2019, 82 p. Available on: http://www.florestal.gov.br/documentos/publicacoes/3759plano-anual-de-outorga-florestal-2019/file. Accessed: 12 jul. 19. 